İşletme Akademisi Dergisi
2020, (4): 294-309
DOI:10.26677/TR1010.2020.626
Dergi web sayfasi: www.sakder.org

Araștirma Makalesi

\title{
Örgütsel Bağlılığın Değişime Karşı Tutuma Etkisinin Belirlenmesi*
}

\section{Öğr. Gör. Özge ÜSTÜN}

Kayseri Üniversitesi Sosyal Bilimler Meslek Yüksekokulu Sağlık Kurumları İşletmeciliği Program1, Kayseri. ozgeustun@kayseri.edu.tr, www.orcid.org/0000-0001-9827-4808

\section{Dr. Öğr. Üyesi Ümit NALDÖKEN}

Cumhuriyet Üniversitesi Sağlık Bilimleri Fakültesi Sağlı Yönetimi A.B.D, Sivas. unaldoken@cumhuriyet.edu.tr, www.orcid.org/0000-0003-1295-8358

\section{Öz}

Bu çalışmanın amacı sağlık kurumlarında çalışanların örgütsel bağlılıklarının ve değişime karşı tutumlarının sosyo-demografik ve tanımlayıcı özelliklerine göre farklılık gösterip göstermediğini belirlemek ve örgütsel bağlılığın değişime karşı tutum üzerindeki etkisini saptamaktır. Sağlık işletmelerindeki çalışanların tutum ve bağlllıkları ifade edilmiştir. Sivas Numune Hastanesi'nde çalışan 1480 personel evren kabul edilerek 434 kişi örnekleme alınarak anket yöntemi kullanılmıştır; 443 çalışandan geri dönüş alınmıştır. Bazı demografik ve kişilik özelliklerine göre örgütsel bağllılık düzeylerinde ve değişime karşı tutumlarında istatistiksel olarak anlamlı farklılık olduğu bulunmuştur. Sivas Numune Hastanesi çalışanlarının örgütsel bağlllıklarının orta düzeyde, değişime karşı tutumlarının ise olumlu olduğu görülmüştür. Araştırma sonucunda, çalışanların örgütsel bağlılık düzeyleri ve değişime karşı tutumları arasında pozitif yönlü ve istatistiksel olarak anlamlı ilişki olduğu saptanmıştır.

Anahtar Kavramlar: Örgütsel Bağlllık, Değişim, Değişime Karşı Tutum

Makale Gönderme Tarihi: 19.07.2020

Makale Kabul Tarihi: 30.11 .2020

*Bu makale "Örgütsel Bağhlı̆̆̆n Değişime Karşı Tutuma Etkisinin Belirlenmesi" adlı yüksek lisans tezinden türetilmiştir.

\section{Önerilen Atıf:}

Üstün, Ö. ve Naldöken, Ü., (2020). Örgütsel Bağlllığın Değişime Karşı Tutuma Etkisinin Belirlenmesi, İsletme Akademisi Dergisi, 1(4): 294-309.

(C) 2020 İşletme Akademisi Dergisi. 


Journal of Business Academy
2020,1 (4): 294-309
DOI:10.26677/TR1010.2020.626
Web pages: www.isakder.org

Research Article

\title{
Determining The Effect of The Attitude of Organizational Commiment Towards to Change
}

\section{Özge ÜSTÜN}

Kayseri University, Social Science Vocational School, Kayseri. ozgeustun@kayseri.edu.tr, www.orcid.org/0000-0001-9827-4808

\section{Dr. Ümit NALDÖKEN}

Cumhuriyet University, Faculty of Health Sciences, Sivas. unaldoken@cumhuriyet.edu.tr, www.orcid.org/0000-0003-1295-8358

\begin{abstract}
This study aims to determine whether the organizational commitment and attitudes towards the change of employees in health institutions differ according to their socio-demographic and descriptive characteristics and to determine the effect of organizational commitment on attitude towards change. The attitudes and loyalties of the employees in healthcare enterprises are expressed. 1480 personnel working in Sivas Numune Hospital were accepted as the universe, as 434 people were sampled and the survey method was used; return received from 443 employees. According to somedemographic and personalityfeatures were found to be statistically significant in organizational commitment levels and attitudes towards change. It was observed that the organizational commitment of the employees of Sivas Numune Hospital was medium and their attitude towards change was positive. As a result of the research, it has been determined that there is a positive and statistically significant relationship between the organizational commitment levels and attitudes towards change.
\end{abstract}

Keywords: Organizational Commitment, Change, Attitude Towards Change

Received: 19.07.2020

Accepted: 30.11 .2020

\section{Suggested Citation:}

Üstün, Ö. ve Naldöken, Ü., (2020). Determining The Effect of The Attitude of Organizational Commiment Towards to Change, Journal of Business Academy, 1(4): 294-309.

(c) 2020 Journal of Business Academy. 


\section{GİRIŞ}

Küreselleşme ile birlikte oluşan teknolojik gelişmeler ve artan rekabet koşulları, örgütlerin etkin olmaları ve varlıklarını devam ettirebilmeleri için ağır rekabet ortamlarında mücadele etmelerini mecbur kılmaktadır. Bu ortamlarda örgütlerin ve yöneticilerin en önemli amaçlarından biri; birincil kaynağı olan çalışanlardan en üst düzeyde verim almak için yetenek ve becerilerini geliştirmeye çalışmaktır. Bu doğrultuda insan faktörü, örgütlerin amaçlarını gerçekleştirmede çok önemli görülmektedir (İraz ve Şimşek, 2004: 107; İleri ve Horasan, 2010: 177).

Yüksek düzeyde örgütsel bağlılığa sahip olan çalışanlar, örgütlerin amaçlarına ulaşmalarında gerekli olan en önemli unsurlardan bir diğeridir. Her çalışan özel durumları sebebiyle örgütleriyle farklı şekillerde ilişkiler geliştirirler. Örgüt çalışanlarının örgütlerine karşı duyumsadıkları farklı şekillerdeki bağlılıklar, örgütsel bağlılığı oluşturmuştur (Guarniccia, 1994: 8; Corder ve Ronnie, 2018: 64).

Rekabet ortamında örgütlerin yaşamsal etkinliklerini devam ettirebilmeleri için değişim zaruri bir durumdur. Örgütlerin kesinlikle adapte olmak zorunda oldukları değişim, onu iyi yönetebilenlere rakipleri karşısında çok önemli avantajlar sağlamaktadır. Örgütler, değişimi önceden hissettikleri takdirde ve değişimi dikkatli takip edip huzlı bir şekilde adapte olabildiklerinde değişim aslında onlar için bir fırsattır (Şahin, 2017: 1, 2).

Çalışma ile örgütlerin amaçları ve rekabet koşulları çerçevesinde değişim ortamını örgütün elindeki insan kaynaklarını ve onların bağlılıklarını kaybetmeden yapabilmeleri için ortaya konulacak olan etkin konumu korumak için önerilerde bulunmak istenmektedir. Çalışmanın amacı ve kapsamı bu doğrultuda belirlenmiştir.

\section{KAVRAMSAL ÇERÇEVE}

\section{1. Örgütsel Bağlılık}

Örgüt; insan topluluklarının belirlenen ortak gayeyi gerçekleştirmek için, iş bölümü yaparak, bir müeyyide gücü ve sorumluluk içinde yaptıkları faaliyetlerin eşgüdümü ve insanların bireysel olarak gerçekleştiremedikleri hedeflerine ulaşmalarını daha güçlü bir biçimde sağlayan sosyal bir araçtır (Terzi, 2000: 1-2). Bağllık ise, kişiyi belirli bir fikre, bireye ya da gruba karşı önceden hazırlayan bir tutum olarak belirtilmektedir (Doğan ve Demiral, 2009: 50). Kavram ve anlama şekli olarak bağlılık; toplum anlayışının olduğu bütün alanlarda olup memurların/işçilerin görevine, askerin ordusuna bağlllığı anlamındaki sadakatli olma durumunu yani sosyal içgüdü duygusunun da bir anlatım şeklidir (Doğan ve Demiral, 2009: 57). Çalışanın sahip olduğu amaç açısından iki ana farklılık ortaya çıkmaktadır. Yapılan tanımların bir takımı örgüt üyesinin belli bir eyleme bağlılığından (genelde örgütte kalma davranışı) bahsederken, diğer bir takım ise örgüt üyelerinin bir varlık olarak örgüte karşı tutumlarına yoğunlaşmaktadır (Çöl ve Gül, 2005: 292; İbicioğlu, 2000: 19).

Örgütsel bağımlılık tanımlamalarının ortak noktası işgörenin işletme hakkında gösterdiği duygusal sadakat çerçevesinde genel olarak aşağıdaki unsurlarla ayırt edildiği söylenebilir (Awamleh, 1996: 65).

- Örgütün gaye ve değerlerine yüksek inanış gösterme.

- Örgüt çıarları için maksimum çaba gösterme.

- Örgüt üyeliğini muhafaza etmek için kuvvetli arzu, örgütte bulunma arzusu ve örgüt hedefleri için çok çalışmak. 
İlk defa 1956 yılında incelenmeye başlayan örgütsel bağlllık örgüte; örgütteki personel devir hızını azaltma, çalışanın uyumunu sağlama, motivasyonu yükseltme, kalite ve verimliliği arttırma, işten ayrılma niyetini azaltma, örgüt için daha fazla çaba gösterilmesi gibi faydalar sağlar (Tutar, 2017: 14; Sarıkaya, 2014: 31). İşgörene örgüt içinde terfi ve yüksek ücretle ödüllendirilmesi ile yüksek düzeyde örgütsel bağlılık elde edilebilir böylece dış çevreden gelen baskılara karşı sadakat devam ettirilebilmesine, örgüt amaçlarının benimsemesine olanak sağlar (Randall, 1987: 464).

Tablo 1' de görüldüğü gibi bireylerin kurumlarına yönelik örgütsel bağl1lık seviyeleri kişisel, örgütsel ve örgüt dışı faktörlere göre değişebilmektedir.

Tablo 1. Örgütsel Bă̆lılı̆̆ı Etkileyen Faktörler

\begin{tabular}{ccc}
\hline Kişisel Faktörler & Örgütsel Faktörler & Örgüt Dışı Faktörler \\
\hline Yaş & İşin Niteliği ve Önemi & Profesyonellik \\
Cinsiyet & Yönetim & Yeni İş Olanakları \\
Eğitim Düzeyi & Ücret Düzeyi & \\
Çalışma Süresi & Örgüt Kültürü & \\
& Örgütsel Adalet & \\
& Örgütsel Ödüller
\end{tabular}

Rol Belirsizliği ve Rol Çatışması

Takım Çalışması

Allen ve Meyer (1990: 1) tarafından ortaya konulan örgütsel bağlllık çeşitlerini kısaca şu şekilde açıklamak mümkündür:

Devam Bağlılı̆̆ı: Çalışanların örgütten ayrıldıklarında bir takım olumsuz durumla karşılaşacaklarını bildiklerinden dolayı, bulundukları örgütte çalışmaya devam etme arzusudur. Başka bir ifadeyle, çalışanın mevcut örgütteki maaş, emeklilik hakları, prim ve sigorta vb. gibi olanaklardan vazgeçmesinin kendisini olumsuz yönde etkileyeceği veya şu anda çalıştığı örgüte seçenek olarak yeni bir iş olanağının kısıtlı olması sonucunda örgütte çalışmaya devam etme arzusu olarak değerlendirilmektedir (Allen ve Meyer, 1990: 3; Gautam vd., 2001: 240). Birey örgüte enerjisini, zamanını, bilgisini ve becerilerini yatırarak girer ve bunun sonucunda örgütten ekonomik ve sosyal faydalar elde eder ancak yatırılmış olunan zaman, enerji, bilgi ve beceri bu kazançların tutarlı olarak devam ettirmesine bağlıdır (Güçlü,2006:13).

Duygusal Bă̆lllık: Çalışanların, kurum ile arasında güçlü duygusal bir bağ hissetmesi ve kurum amaçlarına ve değerlerine olan güçlü inancını ifade etmektedir. Bu bağlılık türü özdeşleşme ve içselleştirme olmak üzere iki ana psikolojik güdüye dayanmaktadır. Bireyin örgüte ait değer ve kuralları kendi değer ve kuralları olarak görmesi ve benimsemesinin söz konusu olduğu içselleştirme; bireysel ve örgütsel değerlerin arasındaki uyuma dayanır (Meyer ve Allen, 1991: 64; Tolay, 2003:5-6; Yüceler, 2009: 446, 447).

Normatif Bağglılık: Bu bağlılık kapsamında duyguları güçlü olan çalışanlar, sorumluluk ve ahlaki endişelerle mevcut kurumlarında kalma eğilimindedirler. Bu bağlllığa sahip çalışanlar, kurumuna karşı sadık olma duygusu içerisinde oldukları için uygun davranışlar göstermekte ve kurumları için uygun olan ne ise o şekilde hareket etme güdüsü ile etkinliklerini sürdürmektedirler. Bu tür bağlılığa sahip olan çalışanlar kurumda kalmayı kendisinde mecburi 
hisseder. Bu bağllıktaki zorunluluk, devam bağlılığında olduğu gibi çıkar ilişkisine dayalı değildir (Allen ve Meyer, 1990: 4; Balay, 2000: 25; Gündoğan, 2009: 60; Ersoy ve Bayraktaroğlu, 2010: 4).

\subsection{Değişim Yönetimi}

İnsanların en önemli özelliklerinden birisi olan daha iyiyi arama dürtüsü ve aynı zamanda değişim ihtiyacının süreklilik gerektirmesi dolayısıyla müşterilerin, bireylerin, kısacası insanların sürekli olarak artan beklentilerini karşılayabilmek için örgütlerin de sürekli olarak kendilerini yenilemeleri, kendilerini aşmaları, yani değişmeleri gerekir. Bu yüzden değişimi yönetemeyenler rekabetçi ortamlarda kendilerini değiştirilmiş olarak buluyorlar (Tunçer, 2013a: 217; Koç,2014: 1).

Bir sistemin planlı ya da plansız bir biçimde bir süreç, sistem veya ortamın belli bir durumdan başka bir duruma geçirilmesine değişim denilmektedir(Sabuncuoğlu ve Tüz,2003: 258). Değişim; üründen ziyade süreçtir, bir uyum aracıdır, faydasına bakılmaksızın, uzun ya da kısa sürede, süratli ya da kademeli, olağan ya da olağandışı şekilde oluşabilir ve olması gerekli bir durumdur (Taner ve Özkan,2013: 217). Başka bir tanım olarak değişim, kısa dönemlerde etkinlik ve işe doyum, orta dönemde gelişme ve uyum, uzun dönemde ise örgüt varlığının sürdürülmesini ifade etmektedir. Değişime yönelik yapılan tanımlar incelendiğinde ortak nokta olarak yenilik, uyum sağlama, hızlı değişen koşullara uyumlu hale gelme ve geleceğe hazırlanma unsurlarından bahsettiği görülür (Marquardt, 1996: 14).

Örgütte meydana gelebilecek herhangi bir değişiklik örgütün mevcut durumunu bozacak ve örgütün değişmesinde bir dengeden başka bir dengeye geçişin söz konusu olduğu yeni bir dengeyi gerekli kılacaktır. Dolayısıyla örgütsel değişimde söz konusu; çevre koşullarına uygun yeni stratejilerin belirlenmesi, yürütülmesi ve uyum gösterilmesidir (Peker,1995: 4). Değişime ayak uydurmanın tek ve en etkili yolu değişim yeteneğine sahip olmaktır. Böylece değişme taraftarı olmayanlar için kestirilemeyen macera gibi gözüken değişimle baş edip fırsata çevirmek kolaylaşacaktır (Töremen 2002: 186). Örgütlerin değişimle ilgili genel amaçları etkinliği, verimliliği, motivasyonu ve tatmin düzeyini artırmaktır bunun yanında güven ve karşılıklı desteği geliştirme, sorunları tartışmalara çözüm getirme, iletişimi geliştirme, pozisyona dayanan otorite yerine ehliyete dayanan otorite sağlama ve sinerji etkisi yaratma gibi amaçları da vardır (Genç, 2007: 317-318). Ayrıca değişim ile işletmelerin yegâne amacı olan kâr elde edebilme ve sürdürülebilirlikte de artış olmaktadır.

\subsubsection{Değişimin Nedenleri}

Küreselleşmenin hızla ilerlemesi ile birlikte gelişen değişimlere ve bunların sonucuna adapte olmaya çalışan örgütler bazı sorunlarla karşılaşmaktadır. Bundan dolayı değişimi zorunlu kılan nedenlerin algılaması, bu uyum sürecini hızlandıracak ve başarıyla aşılmasını kolaylaştıracaktır. Yöneticilerin değişimi zorunlu kılan ögeleri derinlemesine kavrayabilmesi ve bunların her birine uygun reaksiyonlar verebilmesi örgütün değişim süreci ve gelecekteki başarısını doğrudan etkileyecektir. Bir örgütte örgütsel bir değişim uygulanması konusunun ne zaman gündeme alınması gerektiğini belirlemek değişime iten nedenlerin farkında olmak ile mümkün olacaktır (Öztop,2014: 15).

Örgütleri değişimi yönlendiren sebepler duruma göre değişiklik gösterebilmektedir. Çevresel baskılar, örgütsel içinde iletişim kopukluğu, krizler ve çatışmalar, örgütsel performans düşüklüğü, örgüt kültüründe değişme, yasal düzenlemeler ve teknolojik gelişmeler değişme nedenleri arasında sayılmaktadır (Sabuncuoğlu ve Tüz, 2003: 217).

Örgütsel değişime zorlayan faktörleri içsel ve dışsal nedenler bağlamında inceleyecek olursak; içsel nedenler işletmelerin kendi iç bünyelerindeki gelişmeler, durum ve olaylar ile ilgilidir. 
Verimlilik, satış, moral ve güdüleme seviyesindeki düşüşler, kişiler ve gruplar arası yoğun çatışmalar, çalışanların yükselen eğitim seviyesi ve beklentileri gibi faktörler örgütteki bazı değişikliklerin yapılmasını gerektirir (Barutçu, 2000: 53).

Dışsal nedenler bağlamında ise; girdi-süreç-çıktı akışı içinde dış çevre unsurlarının bazıları, örgüt için yeni fırsatlar oluşturacakken bazıları da tehlike oluşturacak yönde değişecektir. Dolayısıyla örgütün bu fırsat ve tehlikeleri tahmin ederek, örgüt yapılarını değiştirmeleri gerekecektir. Aksi takdirde dış çevresi ile uyum sağlamayan, dolasıyla girdi-süreç-çıktı akışı olumsuz olarak etkilenen bir örgüt durumuna gelecektir. Örgütler kendi dış çevrelerini her durumda hazırlıklı ve dikkatli, değişen şartlar üzerinde ani değişiklikler yapabilecek şekilde takip etmelidir (Dursun, 2007:40, 41; Beycioğlu ve Aslan, 2010: 156, 157).

\subsubsection{Değişim Süreci ve Yönetimi}

Değişimi doğru ön görüp, doğru zamanda ve doğru kaynaklarla organize olmak ve buna uygun sistemler geliştirip hayata geçirmeye değişim yönetimi denir. Nerede bulunduğumuzu ve nereye ulaşmak istediğimizi belirledikten sonra, mevcut olduğumuz yerden olmak istediğimiz yere bizi götürecek süreci yönetebilmek değişim yönetimi söz konusudur (Gökbunar ve Ünal, 2003: 185). Diğer tabirle şu anki durumdan arzulanan duruma geçişi sağlayan strateji ve faaliyetler bütünüdür (Karamazarcadik,2007: 47).

Değişim yönetiminde amaç, örgütteki stratejik ve artı değer yaratan süreçlerin yeniden tasarlanmasıdır, radikal bir biçimde değiştirilmesi değildir. Başarı için uygulama süreçlerinde insan faktörü ihmal edilmemelidir. Değişimi fırsat olarak kullanabilmek için, değişim yönetimi kavramının çok iyi bilinmesi ve karşılaşılan hatalardan ders çıkarılması ve bilgi birikiminden akıllıca yararlanılması gerekmektedir (Budak ve Budak,2010: 350).

Değişim yönetiminde başarıyı sağlama değişimi bir süreç olarak görmek ve sürecin sürekliliğini yönetebilmekle sağlanacaktır. Değişim mühendisliği satış ve imalat bölümlerine değil, bu birimlerdeki elemanların yaptıkları işlere uygulanır. Değişim programları içingereken hazırlıkların yapılması, oluşturulması ve uygulanması ile oluşturulan değişim kültürünün kurumda kalıcılaşmasını sağlamak ve bu kültürü geliştirmek için uygun takımlar ve eğitimler büyük öneme sahiptir (Yılmaz,2010: 9).

Değişime yönelik doğru yönelim sağlamak için, kişilerin gerçek anlamda katılımcılık sağlaması gerekmektedir. Köklü değişiklikler getiren bir uygulama olmasından dolayı değişim her zaman gerçekleştirilemez (Yeniçeri, 2002: 126).Değişimin kalıcılı̆̆ını engelleyen en önemli etkenlerden biri de kurumdaki bilgi ve performans yönetimi sistemlerinin yeni düzene uygun olarak yapılandırılmamasıdır (Basım vd., 2009: 42).

\subsubsection{Değişim Yönetiminde Direnç}

Değişme, rutinden vazgeçmeyi gerektirir. Bu nedenle örgüt üyeleri değiş̧imin mevcut durumu daha kötüleştireceği görüşünde bulunurlar. Özellikle direncin gizli olduğu durumlar söz konusu olduğunda ve bu direnç değişim uzmanları tarafından algılanmadığında, değişim faaliyetleri aksayabilir. Çalışanların gizli tepkileri organizasyona bağlılığın ve güdülenmenin azalması, yanlışların artması, devamsızlıkların artması biçiminde olurken, açık dirençleri ise; grevler, işi yavaşlatma, sendikalaşma gibi biçimlerde olabilir (Tevruz,1996: 117).

Değişime direnç, pasif değişime, aktif değişime hatta saldırgan değişime kadar değişen davranış aralığında değerlendirilmektedir. Statükoyu bozan, bilinenden uzaklaştıran ve alışılandan vazgeçmeyi gerektiren değişim rahatsız edicidir ve çalışanlar tarafından dirençle karşılanır. Yaşanan değişimler çalışanlar üzerinde genellikle strese neden olduğundan devamsızlık, iş kazaları, personellerin işinden ve işletmesinden memnuniyetsizliğinin belirtisi olan sürekli 
yorgunluk, isteksizlik, ruhsal çöküntü, sık sinirlenmeler, endişeli bekleyiş gibi tepkiler oluşabilir (Tunçer, 2013b:385).

\section{GEREÇ VE YÖNTEM}

Tanımlayıcı ve kesitsel bir alan araştırması olarak tasarlanan bu çalışmanın amacı sağlık kurumlarında örgütsel bağlılığın değişime karşı tutuma etkisini belirlemektir. Bu amaçla birlikte hem literatüre katkı sağlamak hem de yöneticilere etkili bir değişim yönetimi sistemi kurabilmeleri, çalışanların bağl1lıklarını artırabilmeleri ve böylece amaçlarına daha etkin şekilde ulaşabilmeleri için bazı önerilerde bulunulabileceği düşünülmüştür.

Araştırmada veri toplama aracı olarak anket tekniği kullanılmıştır. Çalışma için ilgili ulusal ve uluslararası literatür taranmış, daha önce yapılmış olan ve geçerlik ve güvenilirliği test edilmiş olan ölçekler kullanılmıştır. Anket başlıca üç bölümden oluşmaktadır. İlk bölümde, katılımcıların demografik ve kişilik özelliklerini belirlemeye yönelik 13 soru yer almaktadır. İkinci bölümde, örgütsel bağlllığın belirlenmesinde, çalışanların duygusal, normatif ve devam bağlılıklarını ölçmek için Meyer ve Allen'in 1997 yılında geliştirilen Wasti tarafından geçerlilik ve güvenilirlik çalışması yapılarak Türkçe' ye uyarlanan 18 sorudan oluşan Örgütsel Bağlılık Ölçeği' dir. 5'li Likert tipinde yapılandırılmıştır. Üçüncü bölümde ise değişime karşı tutumun belirlenmesinde 29 maddeden oluşan, 5'li Likert tipinde yapılandırılmış Seren tarafından 2005 yılında geliştirilen Değişime Karşı Tutum Ölçeği kullanılmıştır. Ölçek, Seren tarafından yapılan faktör analizi sonucuna göre, "değişimde kurumsal politika" (12 madde), "değişimin sonuçları" (8 madde) ve "değişime direnç"( 5 madde) ve "değişimde yönetim tarzı" (4 madde) olarak dört alt boyuta ayrılmıştır.

Örgütsel Bağlılık Ölçeği'nde yer alan ifadelerin güvenilirlik analizi katsayısı (Cronbach's Alpha) 0.79 düzeyindedir. Araştırmaya katılan çalışanlarının değişime karşı tutumlarını belirlemek amacıyla kullanılan ölçeğin güvenilirlik katsayısı ise (Cronbach's Alpha) 0.92 düzeyindedir. Her iki ölçeğin güvenilirlik düzeyi oldukça uygundur.

Anketin uygulandığı tarihlerde Sivas Numune Hastanesi'ndeki 1480 çalışan, çalışmanın evreni olarak kabul edilmiş olup bu evrenden rastgele örnekleme yöntemi ile 434 çalışan örnekleme dahil edilmiştir. Çalışmanın yapılabilmesi için Cumhuriyet Üniversitesi Girişimsel Olmayan Klinik Araştırmalar Etik Kurulu ve Sivas Numune Hastanesi Başhekimliği'nden gerekli izinler alınmıştır.

Çalışmanın evrenini Sivas Numune Hastanesi'nde çalışan 1480 personel oluşturmaktadır. Araştırmada olasılıklı örnekleme yöntemlerinden olan basit rastgele örnekleme yöntemi seçilmiştir. $\alpha=0,05, \mathrm{H}= \pm 0,05$ ve oranlar $\mathrm{p}=0,5$ ve $\mathrm{q}=0,5$ için örneklem büyüklüğü 434 çalışan olarak hesaplanmıştır (Ural ve Kılıç, 2013: 46). 500 anket formu dağııımı sonucu 443 form olarak geri dönüş alınıştır. Ayrıca bazı formların eksik doldurulmuş olması nedeniyle değerlendirme dışı bırakılmıştır.

Araştırmanın amaçları doğrultusunda hipotezler şu şekilde geliştirilmiştir:

Hı:Örgütsel bağlılık düzeyi çalışanların demografik özelliklerine göre anlamlı farklılık vardır.

Hı:Örgütsel bağlılık düzeyi çalışanların cinsiyete göre anlamlı farklılık vardır.

Hıb:Örgütsel bağlılık düzeyi çalışanların yaşa göre anlamlı farklılık vardır.

Hı::Örgütsel bağlılık düzeyi çalışanların eğitim düzeylerine göre anlamlı farklılık vardır.

Hı:Örgütsel bağlılık düzeyi çalışanların medeni durumlarına göre anlamlı farklılık vardır.

Hıe:Örgütsel bağlılık düzeyi çalışanların görevlerine göre anlamlı farklılık vardır. 
Hıf:Örgütsel bağlılık düzeyi çalışanların çalışma sürelerine göre anlamlı farklılık vardır.

$\mathbf{H}_{2}$ : Değişime karşı tutum çalışanların demografik özelliklerine göre anlamlı farklılık vardır.

$\mathbf{H}_{2}$ : Değişime karşı tutum çalışanların cinsiyete göre anlamlı farklılık vardır.

$\mathbf{H}_{2 b}$ : Değişime karşı tutum çalışanların yaşa göre anlamlı farklılık vardır.

$\mathbf{H}_{2 c \text { : }}$ Değişime karşı tutum çalışanların eğitim düzeylerine göre anlamlı farklılık vardır.

$\mathbf{H}_{2 \mathrm{~d}}$ : Değişime karşı tutum çalışanların medeni durumlarına göre anlamlı farklılık vardır.

Hze: Değiş̧ime karşı tutum çalışanların görevlerine göre anlamlı farklılık vardır.

$\mathbf{H}_{2 f}$ : Değişime karşı tutum çalışanların çalışma sürelerine göre anlamlı farklılık vardır.

$\mathbf{H}_{3}$ : Örgütsel bağlılık ve alt boyutları ile değişime karşı tutum vealt boyutları arasında istatistiksel olarak anlamlı ilişki vardır.

\section{BULGULAR}

Bu bölümde demografik faktörler ve kullanılan ölçeklere ilişkin tanımlayıcı istatistiklere yer verilecektir. Ayrıca belirlenen değişkenlerin demografik özelliklere göre farklılıklarına ilişkin bulgulara ve değişkenlerin boyutları arasındaki ilişkiye ait sonuçlara değinilecektir. Ayrıca katılımcıların sosyo-demografik özelliklerine göre örgütsel bağlılık ve değişime karşı tutumların farklılık gösterip göstermediği analiz edilmiştir. Analiz yapılırken "Bağımsız Örneklem T Testi" ve "ANOVA (Tek yönlü varyans analizi)" testi kullanılmıştır. ANOVA testi sonucunda istatiksel olarak anlamlı fark bulunan boyutlar için farkın hangi gruplardan kaynaklandığının tespitinde ise Tukey HSD testi kullanılmıştır.

Tablo 2. Araştırmaya Katılanların Demografik ve Kişisel Özelliklerine Frekans ve Yüzdelik Dağilımları

\begin{tabular}{cccc}
\hline Değişkenler & Kategori & Frekans & Yüzde (\%) \\
\hline Cinsiyet & Kadın & 208 & 47,0 \\
& Erkek & 235 & 53,0 \\
\hline \multirow{2}{*}{ Yaş } & 20 yaş altı & 13 & 2,9 \\
& $21-30$ yaş & 135 & 30,5 \\
& $31-40$ yaş & 168 & 37,9 \\
& $41-50$ yaş & 87 & 19,6 \\
& 50 yaş ve üzeri & 40 & 9,0 \\
\hline \multirow{2}{*}{ Eğitim Düzeyi } & İlköğretim & 10 & 2,3 \\
& Lise & 111 & 25,1 \\
& Önlisans & 85 & 19,2 \\
& Lisans & 177 & 40,0 \\
& Lisansüstü & 60 & 13,5 \\
\hline Medeni Durum & Bekâr & 124 & 28,0 \\
& Evli & 319 & 72,0 \\
\hline \multirow{2}{*}{ Görev } & Tibbi Birimler & 232 & 52,4 \\
& İdari Birimler & 156 & 35,2 \\
& Teknik Birimler & 55 & 12,4 \\
\hline \multirow{2}{*}{ Çalışma Süresi } & 5 ylldan az & 164 & 37,0 \\
& 6-10 yıl & 113 & 25,5 \\
& $11-25$ yıl & 40 & 9,0
\end{tabular}




\begin{tabular}{cccc} 
& $16-20$ yıl & 36 & 8,1 \\
& 20 yıl ve daha fazla & 90 & 20,3 \\
\hline \multirow{3}{*}{ Kurum Yenilikçi mi? } & Evet & 136 & 30,7 \\
& Kısmen & 227 & 51,2 \\
& Hayır & 80 & 18,1 \\
\hline \multirow{2}{*}{ İşinden Memnuniyet } & Çok Memnun & 57 & 12,9 \\
& Memnun & 186 & 42,9 \\
& Kararsız & 151 & 34,1 \\
& Memnun Değil & 27 & 6,1 \\
& Hiç Memnun Değil & 22 & 5,0 \\
\hline \multirow{2}{*}{ İşini Sevme } & Evet & 358 & 80,8 \\
Mesleği Kendi Seçme & Hayır & 85 & 19,2 \\
\hline \multirow{3}{*}{ Tepe Yönetici Yönetim Tarzı } & Evet & 298 & 67,3 \\
& Hayır & 145 & 32,7 \\
\hline & Otokratik & 114 & 25,7 \\
& Yardımsever & 93 & 21,0 \\
& Katılımcı \Destekleyici & 102 & 23,0 \\
& Demokratik & 51 & 11,5 \\
& Diğer & 83 & 18,7 \\
\hline \multirow{2}{*}{ Bir Üst Yönetici Yönetim Tarzı } & Otokratik & 101 & 22,8 \\
& Yardımsever & 76 & 17,2 \\
& Katılımcı\Destekleyici & 125 & 28,2 \\
& Demokratik & 78 & 17,6 \\
& Diğer & 63 & 14,2 \\
\hline
\end{tabular}

Araştırmaya katılan 443 çalışanın kişisel özelliklerine göre frekans ve yüzdelik dağılımları (\%) Tablo 1' de göstermektedir. Ankete katılan çalışanların 235' i (\%53) erkek,168'i (\%37,9) 31 ile 40 yaş aralığında, 177' si (\%40,0) lisans mezunu, 319'u (\%72) evli, 232' si (\%52,4) tıbbi birimlerde, 164' ünün $(\% 37,0)$ çalışma süresi 5 yıldan az, 227' si $(\% 51,2)$ kurumunun kısmen yenilikçi olduğunu düşünüyor, 186' sı (\%42,9) işinden memnun, 358'i $(\% 80,8)$ işini seviyor, 298'i $(\% 67,3)$ mesleğini kendi seçmiş, $114^{\prime}$ ü $(\% 25,7)$ tepe yönetici yönetim tarzını otokratik ve $125^{\prime} \mathrm{i}(\% 28,2)$ bir üst yönetici yönetim tarzını katılımcı/destekleyici olarak görmektedir.

Tablo 3.Demografik Özellikler ile Örgüt Bağlılığı Arasındaki Farklılıkların Analizi

\begin{tabular}{ccccccc}
\hline Eğitim Düzeyi & $\mathbf{n}$ & $\boldsymbol{X}$ & S.S. & $\mathbf{F}$ & $\mathbf{P}$ & Post Hoc. \\
\hline Illköğretim $^{1}$ & 10 & 2,97 & 0,04 & & & \\
Lise $^{2}$ & 111 & 2,91 & 0,49 & & & \\
Ön Lisans $^{3}$ & 85 & 3,04 & 0,43 & \multirow{2}{*}{3,979} & 0,003 & $3-4 \mathrm{p}=0,001$ \\
Lisans $^{4}$ & 177 & 2,81 & 0,45 & & & \\
Lisansüstü & 60 & 2,94 & 0,44 & & & \\
\hline Medeni Durum & & & & & & \\
\hline Bekâr & 124 & 2,78 & 0,50 & $-3,287$ & 0,001 & \\
Evli & 319 & 2,94 & 0,44 & & & \\
\hline Görev & & & & & & \\
\hline Tibbi Birimler & & 232 & 2,89 & 0.39 & & \\
İdari Birimler & \\
Teknik Birimler & & 156 & 2,85 & 0,53 & 3,028 \\
& 55 & 3,04 & 0,50 & & 0,036 & \\
\hline
\end{tabular}


Yapılan analizler sonucunda çalışanların örgütsel bağlılığa ilişkin değerlendirmeleri eğitimdüzeylerine, medeni durumuna ve görevlerine göre istatiksel olarak anlamlı farklılık olduğu; yaşına, cinsiyetine ve çalışma sürelerinegöre anlamlı farklılık olmadığısonucuna varılmıştır.

Tablo 4. Demografik Özellikler ile Değişime Karşı Tutum Arasındaki Farklılıkların Analizi

\begin{tabular}{|c|c|c|c|c|c|c|}
\hline Yaş & $\mathrm{n}$ & $x$ & S.S. & F & $\mathbf{P}$ & Post Hoc. \\
\hline$\leq 20^{1}$ & 13 & 2,90 & 0,44 & \multirow{5}{*}{3,753} & \multirow{5}{*}{0,005} & \multirow{5}{*}{$\begin{array}{c}2-5 \\
p=0,003 \\
3-5 \\
p=0,003\end{array}$} \\
\hline $21-30^{2}$ & 135 & 2,77 & 0,62 & & & \\
\hline $31-40^{3}$ & 168 & 2,78 & 0,52 & & & \\
\hline $41-50^{4}$ & 87 & 2,86 & 0,50 & & & \\
\hline$>50^{5}$ & 40 & 3,12 & 0,43 & & & \\
\hline \multicolumn{7}{|c|}{ Çalışma Süresi } \\
\hline$\leq 5 \mathrm{y}_{1} \mathrm{l}^{1}$ & 164 & 2,82 & 0,57 & \multirow{5}{*}{4,186} & \multirow{5}{*}{0,002} & \multirow{5}{*}{$\begin{array}{c}2-5 \\
p=0,009 \\
3-5 \\
p=0,006\end{array}$} \\
\hline $6-10 \mathrm{y}^{1} \mathrm{l}^{2}$ & 113 & 2,74 & 0,60 & & & \\
\hline $11-15 y_{1} l^{3}$ & 40 & 2,64 & 0,54 & & & \\
\hline $16-20 \mathrm{yll}^{4}$ & 36 & 2,90 & 0,41 & & & \\
\hline$>20 \mathrm{yil}^{5}$ & 90 & 2,99 & 0,43 & & & \\
\hline
\end{tabular}

Çalışanların değişime karşı tutuma ilişkin değerlendirmeleri yaş ve çalışma süresi grupları ile istatistiksel olarak anlamlı farklılık olduğu; cinsiyet, eğitim düzeyi, medeni durum ve görevleri ile istatistiksel olarak anlamlı farklılık olmadığını göstermektedir.

Tablo 5. Kişisel Özellikler ile Örgüt Bağhılığı Arasındaki Farklılıkların Analizi

\begin{tabular}{|c|c|c|c|c|c|c|}
\hline Kurumun Yenilikçi Olması & $\mathbf{n}$ & $x$ & S.S. & $\mathbf{F}$ & $\mathbf{P}$ & Post Hoc. \\
\hline Evet $^{1}$ & 136 & 2,95 & 0,48 & \multirow{3}{*}{6,644} & \multirow{3}{*}{0,001} & $1-3$ \\
\hline Kismen $^{2}$ & 227 & 2,93 & 0,41 & & & $\mathrm{p}=0,002$ \\
\hline Hayır $^{3}$ & 80 & 2,73 & 0,52 & & & $2-3$ \\
\hline \multicolumn{7}{|l|}{ İşinden Memnuniyet } \\
\hline Çok Memnun ${ }^{1}$ & 57 & 2,97 & 0,54 & \multirow{5}{*}{4,993} & \multirow{5}{*}{0,001} & $1-4$ \\
\hline Memnun² & 186 & 2,92 & 0,43 & & & $\mathrm{p}=0,002$ \\
\hline Kararsiz ${ }^{3}$ & 151 & 2,94 & 0,45 & & & $2-4$ \\
\hline Memnun Değil ${ }^{4}$ & 27 & 2,57 & 0,31 & & & $\mathrm{p}=0,003$ \\
\hline Hiç Memnun Değil ${ }^{5}$ & 22 & 2,71 & 0,49 & & & $3-4$ \\
\hline \multicolumn{7}{|l|}{$\begin{array}{c}\text { Tepe Yönetici Yönetim } \\
\text { Tarzı }\end{array}$} \\
\hline Otokratik ${ }^{1}$ & 114 & 2,77 & 0,54 & \multirow{5}{*}{5,016} & \multirow{5}{*}{0,001} & \\
\hline Yardımsever ${ }^{2}$ & 93 & 3,01 & 0,32 & & & $p=0,000$ \\
\hline Katılımc1/Destekleyici ${ }^{3}$ & 102 & 2,85 & 0,54 & & & $1-5$ \\
\hline Demokratik $^{4}$ & 51 & 2,91 & 0,33 & & & $\mathrm{p}=0,005$ \\
\hline Diğer $^{5}$ & 83 & 3,00 & 0,38 & & & \\
\hline
\end{tabular}

Çalışanların örgütsel bağlılığa ilişkin değerlendirmeleri kurumun yenilikçi olup olmamasına, işinden memnuniyetlerine ve tepe yönetici yönetim tarzlarına göre istatistiksel olarak anlamlı bir 
farklılık olduğu; işini sevme, bir üst yönetici yönetim tarzı ve mesleğini kendi seçme durumlarına göre istatistiksel olarak anlamlı farklılık olmadığı sonucuna varılmıştır.

Tablo 6. Kişisel Özellikler ile Değişime Karşı Tutum Arasındaki Farklılıkların Analizi

\begin{tabular}{|c|c|c|c|c|c|c|}
\hline İşini Sevme & $\mathbf{n}$ & $x$ & S.S. & $\mathrm{T}$ & $\mathbf{P}$ & Post Hoc. \\
\hline Evet & 358 & 2,89 & 0,50 & \multirow[b]{2}{*}{5,413} & \multirow[b]{2}{*}{0,000} & \\
\hline Hayır & 85 & 2,54 & 0,64 & & & \\
\hline \multicolumn{7}{|l|}{$\begin{array}{c}\text { Kurumun Yenilikçi } \\
\text { Olması }\end{array}$} \\
\hline Evet $^{1}$ & 136 & 3,05 & 0,4 & \multirow{3}{*}{86,15} & \multirow{3}{*}{0,000} & $1-2$ ile $1-3$ \\
\hline Kismen $^{2}$ & 227 & 2,91 & 0,44 & & & $\mathrm{p}=0,018$ \\
\hline Hayır $^{3}$ & 80 & 2,22 & 0,60 & & & \\
\hline \multicolumn{7}{|l|}{ İşinden Memnuniyet } \\
\hline Çok Memnun ${ }^{1}$ & 57 & 3,00 & 0,55 & \multirow{5}{*}{11,51} & \multirow{5}{*}{0,000} & $1-4$ ile $1-5$ \\
\hline Memnun ${ }^{2}$ & 186 & 2,89 & 0,47 & & & $\mathrm{p}=0,000$ \\
\hline Kararsiz ${ }^{3}$ & 151 & 2,83 & 0,53 & & & \\
\hline Memnun Değil ${ }^{4}$ & 27 & 2,38 & 0,49 & & & 2-4 ile $2-5$ \\
\hline Hiç Memnun Değil ${ }^{5}$ & 22 & 2,36 & 0,77 & & & $\mathrm{p}=0,000$ \\
\hline \multicolumn{7}{|l|}{$\begin{array}{l}\text { Tepe Yönetici } \\
\text { Yönetim Tarzı }\end{array}$} \\
\hline Otokratik $^{1}$ & 114 & 2,54 & 0,66 & \multirow{5}{*}{15,67} & \multirow{5}{*}{0,000} & 1-2 ile 1-3 \\
\hline Yardımsever ${ }^{2}$ & 93 & 2,88 & 0,39 & & & $\mathrm{p}=0,000$ \\
\hline Katılımc1/Destekleyici³ & 102 & 2,96 & 0,49 & & & \\
\hline Demokratik $^{4}$ & 51 & 3,14 & 0,37 & & & 1-4 ile $1-5$ \\
\hline Diğer ${ }^{5}$ & 83 & 2,81 & 0,50 & & & \\
\hline \multicolumn{7}{|l|}{$\begin{array}{l}\text { Bir Üst Yönetici } \\
\text { Yönetim Tarzı }\end{array}$} \\
\hline Otokratik $^{1}$ & 101 & 2,69 & 0,68 & \multirow{5}{*}{13,91} & \multirow{5}{*}{0,000} & \multirow{2}{*}{$\begin{array}{c}1-3 \text { ile } 1-4 \\
p=0,000\end{array}$} \\
\hline Yardımsever ${ }^{2}$ & 76 & 2,73 & 0,46 & & & \\
\hline Katılımcı/Destekleyici³ & 125 & 3,01 & 0,47 & & & \\
\hline Demokratik $^{4}$ & 78 & 3,04 & 0,43 & & & 2-3 ile $2-4$ \\
\hline Diğer 5 & 63 & 2,55 & 0,46 & & & $\mathrm{p}=0,002$ \\
\hline
\end{tabular}

Çalışanların değişime karşı tutuma ilişkin değerlendirmelerinde işlerini sevme, kurumun yenilikçi olup olmadığı, işinden memnuniyet durumları, bir üst yönetici yönetim tarzları ve tepe yönetici yönetim tarzlarına göreistatistiksel olarak anlamlı bir farklılık olduğu; mesleğini seçme durumuna göre istatistiksel olarak anlamlı bir farklılık olmadığını göstermektedir $(p<0,05)$. 
Tablo 7. Örgütsel Bağlılık ve Değişime Karşı Tutum Boyutları Arasındaki İlişkinin Analizi

\begin{tabular}{llll}
\hline Değişkenler Duygusal Bağlılık & Normatif Bağlılık & Devam Bağlılı̆ğ
\end{tabular}

\begin{tabular}{lccc}
\hline Kurumsal Politika & $0,166^{* *}$ & $0,254^{* *}$ & $0,359^{* *}$ \\
Değişim Sonuçları & $0,206^{* *}$ & $0,283^{* *}$ & $0,428^{* *}$ \\
Değişime Direnç & $0,132^{*}$ & $0,097^{*}$ & $0,146^{*}$ \\
Değişimde Yönetim Tarzı & $0,229^{* *}$ & $0,181^{* *}$ & $0,381^{* *}$ \\
& & & \\
\hline
\end{tabular}

Not: ${ }^{* *} \mathrm{p}<0,01$ anlamlı ilişki, ${ }^{*} \mathrm{p}<0,05$ anlamlı ilişki, In=434

Duygusal bağlılık alt boyutu ile kurumsal politika $(0,166)$, değişim sonuçları $(0,206)$, değişime direnç $(0,132)$, değişimde yönetim tarzı $(0,229)$ alt boyutları arasında düşük düzeyli ve pozitif ilişki vardır. Normatif bağlılık alt boyutu ile kurumsal politika $(0,254)$, değişim sonuçları $(0,283)$, değişime direnç $(0,097)$, değişimde yönetim tarzı $(0,181)$ alt boyutları arasında düşük düzeyli ve pozitif ilişki vardır. Devam bağlılığı alt boyutu ile kurumsal politika $(0,359)$, değişime direnç $(0,146)$, değişimde yönetim tarzı $(0,381)$ alt boyutları arasında düşük düzeyli; değişim sonuçları $(0,428)$ alt boyutu ile ise orta düzeyli ve pozitif ilişki vardır. Genel olarak örgütsel bağlllık ve alt boyutları düzeyi arttıkça değişime karşı tutum ve alt boyutları düzeyi de artmaktadır.

\section{SONUÇ VE ÖNERILER}

Sivas Numune Hastanesi'nde çalışanların örgütsel bağlllık ve değişime karşı tutum düzeylerinin sosyo-demografik ve tanımlayıcı özelliklerine göre farklılık gösterip göstermediğini belirlemek ve örgütsel bağllı̆̆ın değişime karşı tutuma etkisini incelemek amacıyla yapılan bu çalışmadan elde edilen bulgular doğrultusunda sonuçları açıklanmaktadır.

Demografik ve kişilik özelliklere göre yapılan analizlerde örgütsel bağlllık düzeyleri incelendiğinde; cinsiyete, yaşa, çalışma sürelerine, çalışanların işlerini sevmelerine, bir üst yönetici yönetim tarzına ve mesleklerini kendi seçmesine göre istatistiksel olarak anlamlı farklılık olmamasına rağmen medeni durumları, eğitim düzeyleri, görevleri, kurumun yenilikçi olup olmaması, işinden memnuniyeti ve tepe yönetici yönetim tarzına göre istatistiksel olarak anlamlı farklılık bulunmuştur. Araştırmaya katılan evlilerin örgütsel bağllık düzeylerinin bekârlardan daha fazla olduğu söylenebilir. Ön lisans mezunlarının lisans mezunlarına göre, teknik hizmet çalışanlarının idari hizmet çalışanlarına göre daha fazla olduğu da söylenebilir.

Aynı şekilde demografik ve kişilik özelliklere göre değişime karşı tutumları incelendiğinde; cinsiyet, görev, eğitim düzeyleri, medeni durum ve mesleklerini kendi seçme değişkenleri istatiksel olarak anlamlı değil iken yaşlarına, çalışma süresilerine, işini sevmesine, kurumun yenilikçi olup olmamasına, işinden memnuniyetine, tepe yönetici yönetim tarzına ve bir üst yönetici yönetim tarzına göre istatiksel olarak farklılık göstermektedir. Araştırmaya katılan 50 yaş üstü çalışanların değişime karşı tutum düzeyleri 21-30 yaş aralığında ve 31-40 yaş aralığında olanlara daha olumludur. Çalışma süresi 20 yıldan fazla olan çalışanların 6-10 yıl aralığında ve 11-15 yıl aralığında olan çalışanlara göre daha olumludur.

Korelasyon analizi bulguları doğrultusunda örgütsel bağlılık düzeyi artarsa değişime karşı tutum olumlu olmaktadır veya değişime karşı tutum olumlu olduğu sürece örgütsel bağlılık düzeyi artmaktadır. 
Bu sonuçlara göre çalışma amacı ve kapsamında $\mathbf{H}_{3}$ hipotezi ve $\mathbf{H}_{1 c}, \mathbf{H}_{1 d}, \mathbf{H}_{1 e}, \mathbf{H}_{2 b}, \mathbf{H}_{2}$ falt hipotezleri kabul edilmiş olup $\mathbf{H}_{1 a}, \mathbf{H}_{1 \mathbf{b}}, \mathbf{H}_{1 \mathbf{f}}, \mathbf{H}_{2 \mathrm{a}}, \mathbf{H}_{2 \mathrm{c}}, \mathbf{H}_{2 \mathrm{~d}} \mathbf{H}_{2 \mathrm{ealt}}$ hipotezleri reddedilmiştir.

Çalışanların örgütsel bağlllıklarının ortalama düzeyde olduğu ile ilgili bulgu Çoban ve Demirtaş'ın (2011), Yıldız'ın (2013), Atik ve Üstüner'in (2014), Doğruöz ve Özdemir'in (2018), Koyuncu (2019) örgütsel bağlılık ile ilgili çalışma sonuçları ile benzerlik göstermektedir. Çalışanların değişime karşı tutumlarının ise orta düzeyde olduğu ile ilgili bulgu Çelik (2018), Çakın (2019)' in çalışmalarının sonucu bu çalışma ile benzerlik göstermektedir.

Örgütsel Bağllık Ölçeği'nde en düşük ortalamayı alan “Çalıştı̆̆ım iş yerine çok şey borçluyum.” ifadesidir. Bu değerlendirmeden yola çıkarak araştırmanın yapıldığı hastane boyutunda kurum yöneticileri örgüt üyelerinin bağlllıklarını artırmak için çalışanların kendilerini daha fazla geliştirmelerine olanaklar ve fırsatlar sağlayacak örgüt ortamı yaratmalıdır.

Değişime Karşı Tutum Ölçeği'nde en düşük ortalamayı alan “Değişim ile ilgili istenen davranışı gösterdiğimde ödüllendiriliyorum." ifadesidir. Bu sebeple araştırmanın yapıldığı hastanedeki çalışanların değişime karşı tutumlarını daha pozitif hale getirmek isteyen ve değişimi iyi yönetmek isteyen kurum yöneticileri örgüt üyelerinin değişime karşı olumlu tutumlar sergilediklerinde onları ödüllendirmelidir.

Örgütsel bağlılık ve değişime karşı tutum arasındaki ilişkiden dolayı çalışanların değiş̧ime karşı tutumlarını daha olumlu hale getirmek gayesi taşıyan örgütler çalışanların örgütsel bağlllık düzeylerini arttırmaya yönelik faaliyetlerde bulunmalıdırlar.

Literatüre katkı sağlanması amacıyla örgütsel bağlılık ve değişime karşı tutum ölçekleri ile yapılacak değerlendirme çalışmalarında başka bir yapı tarzına sahip üretim işletmesi veya özel hastane bağlamında karşılaştırılması; örgütsel güven veya çalışan memnuniyeti gibi değişkenler de dahil edilerek yapılması önerilmektedir.

\section{KAYNAKÇA}

Allen, N. J. ve Meyer, J. P. (1990). The Measurement and Antecedents of Affective, Continuance and Normative Commitment to The Organization. Journal of Occupational Psychology, 63 (1), 1-18.

Atik, S. ve Üstüner, M. (2014). İlköğretim Okullarının Örgüt Tipi İle Öğretmenlerin Örgütsel Bağllı̆̆ğı Arasındaki İlişki. Ahi Evran Üniversitesi Kırşehir Ĕ̆itim Fakültesi Dergisi, 15 (2), 133-154.

Awamleh, N. A. H. K. (1996). Organizational Commitment of Civil Service Managers in Jordan: A Field Study. Journal of Management Development, 15 (5), 65-74.

Balay, R. (2000). Yönetici ve Öğretmenlerde Örgütsel Bă̆lllık. Ankara: Pegem Akademi Yayıncıllk.

Barutçu, E. (2000). Örgütsel Değişim Yönetimi ve Denizli Tekstil İşletmelerinde Bir Uygulama. (Doktora Tezi). Selçuk Üniversitesi Sosyal Bilimler Enstitüsü, Konya.

Basım H. N., Şeşen H. ve Çetin, F. (2009). Değişim ve Örgütler. A. K. Varoğlu ve H. N. Basım (Ed.), Örgütlerde Değişim ve Öğrenme içinde. Ankara: Siyasal Yayınları.

Beycioğlu, K. ve Aslan, M. (2010). Okul Gelişiminde Temel Dinamik Olarak Değişim ve Yenileşme: Okul Yöneticileri ve Öğretmenlerin Rolleri. Yüzüncü Yıl Üniversitesi Eğitim Fakültesi Dergisi, 7 (1), 153-173.

Corder, E. ve Ronniel, L. (2018). The Role of The Psychological Contract in The Motivation of Nurses. Leadership in Health Services, 31 (1), 62-76. 
Çakın, A. (2019). Hemşirelerin Bireysel Yenilikçilik Düzeylerinin Değişime Karşı Tutumlarına Etkisinin İncelenmesi. (Yüksek Lisans Tezi). Manisa Celal Bayar Üniversitesi Sağlık Bilimleri Enstitüsü, Manisa.

Çelik, Ö. G. (2018). Hemşirelerin Örgüt İklimi Alg̨larının Ve Değişime Karşı Tutumlarının Belirlenmesi. (Yüksek Lisans Tezi). Marmara Üniversitesi Sağlık Bilimleri Enstitüsü, İstanbul.

Çoban, D. ve Demirtaş, H. (2011). Okulların Akademik İyimserlik Düzeyi ile Öğretmenlerin Örgütsel Bağlllı̆̆ı Arasındaki İlişki. Kuram ve Uygulamada Eğitim Yönetimi Dergisi, 17 (3), 317-348.

Çöl, G. ve Gül, H. (2005). Kişisel Özelliklerin Örgütsel Bağlllık Üzerine Etkileri ve Kamu Üniversitelerinde Bir Uygulama. Atatürk Üniversitesi İktisadi ve İdari Bilimler Dergisi, 19 (1), 291-306.

Doğan, S. ve Demiral, Ö. (2009). Örgütsel Bağlllı̆̆ın Sağlanmasında Personel Güçlendirme ve Psikolojik Sözleşmenin Etkisine İlişkin Bir Araştırma. Erciyes Üniversitesi İktisadi ve İdari Bilimler Fakültesi Dergisi, 22 (32), 47-80.

Doğruöz, E. ve Özdemir, M. (2018). Eğitim Örgütlerinde Üretim Karşıtı İş Davranışları ve Örgütsel Bağllık İlişkisi. İlköğretim Online, 17 (1), 396-413.

Dursun, E. (2007). Örgütsel Değişim ve Değişim Karşısında Bireysel Direnç. (Yüksek Lisans Tezi). Dumlupınar Üniversitesi Sosyal Bilimler Enstitüsü, Kütahya.

Ersoy, S. ve Bayraktaroğlu, S. (2010). Örgütsel Bağlılık. D. E. Özler (Ed.), Örgütsel Davranışta Güncel Konular içinde, İstanbul: Ekin Yayın Evi.

Gautam, T., Van Dick, R. ve Wagner, U. (2001). Organizational Commitment in Nepalese Settings. Asian Journal of Social Psychology, 4 (3), 239-248.

Gökbunar, R. ve Ünal, A. (2003). Özel Sektörde ve Kamu Sektöründe Değişim. C. C. Aktan (Ed.), Moderniteden Postmodernitiye Değişim içinde. Konya: Çizgi Kitapevi.

Guarnaccia, S. (1994). In Practice-Healthy Companies. Training \& Development Journal, 48 (3), 6-9.

Güçlü, H. (2006). Turizm Sektöründe Durumsal Faktörlerin Örgütsel Bă̆lllık Üzerindeki Etkisi. Eskişehir: Anadolu Üniversitesi Yayınları.

Gündoğan, Tamer (2009). Örgütsel Bă̆lılık: Türkiye Cumhuriyet Merkez Bankası Uygulaması. (Uzmanlık Yeterlilik Tezi). Ankara: T.C. Merkez Bankası.

İbicioğlu, H. (2000). Örgütsel Bağlllıkta Paradigmatik Uyumun Yeri. Dokuz Eylül Üniversitesi İktisadi İdari Bilimler Fakültesi Dergisi, 15 (1).

İleri, H. Ve Horasan, A. (2010). Küresel Rekabet Ortamında İşletmelerin Teknoloji ve Ar-Ge Yönetimlerinin Rekabete Etkileri Üzerine Araştırma ve Örnek Bir Uygulama. Selçuk Üniversitesi Sosyal Bilimler Meslek Yüksekokulu Dergisi, 13 (1-2), 171-190.

İraz, R. ve Şimşek, G. (2004). Örgütsel Değişimin Gerçekleştirilmesinde Liderliğin Rolü: Transformasyonel Liderlik İncelemesi. Sosyal Ekonomik Araştırmalar Dergisi, 4(7), 99-117.

Karabulut, N. (2013). Hekim ve Hemşirelerin Örgütsel Bă̆lllık, İş Doyumu ve Tükenmişlik Durumlarmın Değerlendirilmesi. (Yüksek Lisans Tezi). Cumhuriyet Üniversitesi Sağlık Bilimleri Enstitüsü, Sivas.

Karamazarcadik, A. (2007). Sayıştayda Değişim Yönetimi. Sayıştay Dergisi, 18 (65), 43-52. 
Koç, Z. (2014). Örgütsel Değişim, Değişim Yönetimi ve Örgütsel Davranışlar Üzerine Örnek Bir Uygulama. (Yüksek Lisans Tezi). Bahçeşehir Üniversitesi Sosyal Bilimler Enstitüsü, İstanbul.

Koyuncu, A. (2019). Öğretmenlerin Örgütsel Bağhllıkları ile Değişime Hazır Olma Durumları Arasındaki İlişki. (Yüksek Lisans Tezi). Ondokuz Mayıs Üniversitesi Eğitim Bilimleri Enstitüsü, Samsun.

Marquardt, M. J. (1996). Building The Learning Organization. New York: McGraw-Hill.

Meyer, J. P., Allen, N. C. ve Smith, C.A. (1993). Commitment to Organizations and Occupations: Extension and Test of a Three-Component Conceptualization, Journal of Applied Psychology, 78 (4), 538-551.

Meyer, J. P., Allen, N. J. (1991). A Three-Component Conceptualization of Organizational Commitment. Human Resource Management Review, 1 (1), 61-89.

Öztop, S. (2014). Kamu Çalışanlarının Örgütsel Değişim Yönetimi Uygulamalarına Yönelik Algısı. (Doktora Tezi). Süleyman Demirel Üniversitesi Sosyal Bilimler Enstitüsü, Isparta.

Peker, Ö. (1995). Yönetimi Geliştirmenin Sürekliliği. Ankara: Türkiye ve Orta Doğu İdaresi Enstitüsü Yayınları.

Randall, D. M. (1987). Commitment and the Organization: The Organization Man Revisited. Academy of Management Review, 12 (3), 460-471.

Sabuncuoğlu, Z. ve Tüz, M. (2003). Örgütsel Psikoloji. Bursa: Furkan Ofset.

Sarıkaya, Ö. (2014). Çalışanların Örgütsel Bağhllık ve İş Tatmin Düzeylerinin İncelenmesi. (Yüksek Lisans Tezi). Beykent Üniversitesi Sosyal Bilimler Enstitüsü, İstanbul.

Seren, Ş. (2005). Değişime Karşı Tutum Ölçeğinin Geliştirilmesi ve Kalite Belgesi Alan Hastanelerde Değişim ile Örgüt Kültürü Arasındaki İlişkinin İncelenmesi. (Doktora Tezi). İstanbul Üniversitesi Sağllk Bilimleri Enstitüsü, İstanbul.

Şahin, T. (2017). Örgütsel Değişimin Çalı̧̧anların Güven ve Bağlllık Düzeyleri Üzerindeki Etkisi ve Bir Uygulama. (Doktora Tezi). İstanbul Ticaret Üniversitesi Sosyal Bilimler Enstitüsü, İstanbul.

Taner, B. ve Özkan, C. (2013). Kalite Yönetim Sistemi ve Yaşanan Değişime İlişkin Tutumlar: Mersin Üniversitesi Örneği. Çukurova Üniversitesi Sosyal Bilimler Enstitüsü Dergisi, 22(1), 213-228.

Terzi, A. R. (2000). Örgüt Kültürü. Ankara: Nobel Yayın Dağıtım.

Tevruz, S. (1996). Endüstri ve Örgüt Psikolojisi. Ankara: Türk Psikologlar Derneği.

Töremen, F. (2002). Eğitim Örgütlerinde Değişimin Engel ve Nedenleri. Fırat Üniversitesi Sosyal Bilimler Dergisi, 12 (1), 185-202.

Tunçer, P. (2013a). Örgütsel Değişim Sürecinde Öğrenen Örgütler ve Örgüt Geliştirme. Sosyal Bilimler Araştırmaları Dergisi, 8 (1), 214-244.

Tunçer, P. (2013b). Değişim Yönetimi Sürecinde Değişime Direnme. Ondokuz Mayıs Üniversitesi Eğitim Fakültesi Dergisi, 32 (1), 373-406.

Tutar, H. N. G. (2017). İş Yerindeki Yıldırma Davranışlarının İşten Ayrılma Niyeti Üzerindeki Etkisi: Örgütsel Bağ̆llık ve Örgütsel Sessizlĭgin Aracılık Rolü. (Yüksek Lisans Tezi). Mustafa Kemal Üniversitesi Sosyal Bilimler Enstitüsü, Hatay. 
Ural, A. ve Kılıç, İ. (2013). Bilimsel Araştırma Süreci ve Spss ile Veri Analizi. Ankara: Detay Yayınları.

Yeniçeri, Ö. (2002). Örgütsel Değişmenin Yönetimi. Ankara: Nobel Yayınları.

Yıldız, K. (2013). Örgütsel Bağlılık İle Örgütsel Sinizm ve Örgütsel Muhalefet Arasındaki İlişki. International Periodical For The Languages, 8 (6), 853-879.

Yılmaz, E. (2010). Hasta Memnuniyeti Odaklı Değişim Yönetimi. (Yüksek Lisans Tezi). Beykent Üniversitesi Sosyal Bilimler Enstitüsü, İstanbul.

Yüceler, A. (2009). Örgütsel Bağlllık ve Örgüt İklimi İlişkisi: Teorik ve Uygulamalı Bir Çalışma. Selçuk Üniversitesi Sosyal Bilimler Enstitüsü Dergisi, 18 (22), 445-458. 